\title{
Sustainable Production of Bioenergy Feedstock from the Industrial Forest: Potential and Challenges of Operational Scale Implementation
}

\author{
Jami Nettles ${ }^{1} \cdot$ Peter Birks $^{1} \cdot$ Eric Sucre $^{2} \cdot$ Robert Bilby $^{3}$
}

Published online: 1 December 2015

(C) Springer International Publishing AG 2015

\begin{abstract}
There is increasing interest in energy from woody biomass as fossil fuel replacement, yet environmental and economic limitations have reduced feedstock available for bioenergy. Supply could likely be substantially increased with intensive forest management for productivity and utilization as well as forest-based dedicated energy crops. This paper discusses the role of industrial forests in sustainable bioenergy feedstock production and the lessons learned in an operational scale project. Catchlight Energy, LLC, a Chevron|Weyerhaeuser joint venture, evaluated intercropping switchgrass (Panicum virgatum) in loblolly pine plantations for liquid transportation fuel, with the goal of full-scale production. Within Weyerhaeuser, sustainability and operational research were conducted simultaneously. While the environmental research is non-proprietary and being published as it is completed, operational trials were internal. To understand lessons learned, staff responsible for management, planning, logistics, and field operations were interviewed, and perceived and actual barriers to production described. Ongoing environmental research is showing that carefully planned field operations can be conducted sustainably, but energy crop production fell below levels needed for economic feasibility.
\end{abstract}

This article is part of the Topical Collection on Sustainable and Renewable Fuels

Jami Nettles

jami.nettles@weyerhaueser.com

\footnotetext{
Weyerhaeuser Company, Columbus, MS, USA

Weyerhaeuser Company, New Bern, NC, USA

3 Weyerhaeuser Company, Federal Way, WA, USA
}

Keywords Bioenergy · Industrial forest · Operational scale implementation · Greenhouse gases · GHG

\section{Introduction}

Increasing concern over impacts of elevated concentrations of greenhouse gases (GHG) in the atmosphere on climate has generated interest in replacing energy from fossil fuels with energy from forests, with woody biomass possibly accounting for $18 \%$ of global energy consumption by 2050 [1]. However, it is likely that this value could be substantially increased by developing and implementing forest management measures to enhance biomass productivity and utilization and also grow dedicated energy crops.

While woody biomass may be defined as "all forest plant and forest-plant-derived materials" [2], not all woody biomass is grown in a forest nor is it the only potential feedstock from the forest. Forest-based bioenergy crops can come from increased management and use of trees grown for traditional forest products or from dedicated feedstock grown specifically for bioenergy. Short-rotation woody crops are an important source of biomass but are typically grown agriculturally.

Recent efforts have focused on innovations to make second-generation biofuel technically and economically feasible. Initial estimates showed adequate feedstock to meet the Renewable Fuel Standard [3], but models over-allocated woody biomass to bioenergy uses [4] and environmental and economic limitations make actual supply much lower than potential availability [5, 6]. Capital for investment in conversion was limited by the economic recession, energy costs dropped, and high-profile failures in wood-based biofuel conversion facilities [7] reduced willingness of growers to plant bioenergy-specific feedstock. 
However, there are still US wood-based cellulosic biofuel planned and in place, although only one is ready for commercial scale production [7]. European markets will depend on US woody biomass to meet renewable fuel targets [8]. With careful landscape planning, industrial forestry could source a large, stable source of biomass without affecting food supply, bring experience in large-scale sustainable land management, and provide a balanced economic and market portfolio of products.

\section{Forest-Based Feedstock}

\section{Increased Management and Use of Forests Grown for Traditional Forest Products}

While there was initial concern that a market for forest-based sources of biomass would cause conversion of forest to more intensive land uses, bioenergy production need not lead to deforestation [9], and demand could lead to increased forest area [10]. More intensive biomass removal from public forests could work within fuel load reduction and pest management plans to remove understory and manage stand density [11]. For small private landowners, increased utilization of existing forest biomass requires less investment and risk than dedicated plantings. More intensive management could include fertilization, denser plantings, more frequent thinning of noncrop trees, or understory harvest. Forest residues could be an important bioenergy feedstock, making up $13 \%$ of the US potential biomass [12] and displacing about $3 \%$ of electricity sector carbon (based on 1997 FIA and energy data) [13]. Figure 1, produced by the National Renewable Energy Laboratory based on US Forest Service data, shows residues available for biomass removal.

Increased residue usage is most easily accomplished by whole-tree harvest, with natural understory vegetation harvested mechanically [14-16]. Periodic natural understory vegetation would be more variable than a dedicated crop, causing potential conversion issues. Increased residue use and understory removal would be subject to applicable regulatory forest practice rules, state Best Management Practices, certification guidelines, and other environmental regulations, such as the Clean Water Act. Participation within forest certification systems, such as the Sustainable Forestry Initiative ${ }^{\circledR}\left(\mathrm{SFI}^{\circledR}\right)$, Programme for the Endorsement of Forest Certification (PEFC), American Tree Farm System ${ }^{\circledR}$ (AFTS), and Forest Stewardship Council ${ }^{\circledR}$ (FSC) [17], has expanded rapidly over the last decade, and many standards associated with these certification programs are applicable to forest biomass production.

Sustainability of intensive removals from forests depends on the specific practice and site. Eisenbies et al. [12] synthesized study data on biomass left after current stem-only harvest and found that whole-tree harvest could remove 20 $50 \%$ of material now retained after harvest. They cite conflicting evidence as to which sites are most resilient, but that it is possible to remove residue without depleting nutrients and reducing site productivity. Many studies have found little to no effect of these types of removals on soil quality [18-20], though aggressive biomass removal may impact soil productivity. On poorer loblolly pine (Pinus taeda) sites, often with coarse-textured soils, intensive biomass removal is more likely to reduce productivity [21-24], and higher slope areas are more susceptible to erosion from biomass removal [25]. Removal of harvest residues on sites that are already deficient in organic matter/soil carbon may remove a higher proportion of available $\mathrm{C}$ and nutrients from the site than would occur on sites with higher levels of organic matter.

\section{Dedicated Forest-Based Feedstock Grown Specifically for Bioenergy}

There are many hurdles to growing a purpose-grown bioenergy crop on forest land, but future scenarios may require more bioenergy feedstock than is available from existing agriculture and forest landscapes. These crops could include low-value trees or perennial energy crops, either intercropped in or grown in a mosaic with traditional plantations. However, much of what we know comes from plot-scale trials or agricultural studies. Weyerhaeuser Company installed, to our knowledge, the only purpose-grown bioenergy crop at operational scale within a forested system.

Weyerhaeuser's bioenergy project was initiated in 2008 as part of Catchlight Energy, LLC, a Chevron|Weyerhaeuser joint venture, to evaluate intercropping switchgrass (Panicum virgatum) in loblolly pine plantations for liquid transportation fuel. Switchgrass is a native $\mathrm{C} 4$ grass, and there is a large body of research and guidance in growing it for bioenergy in agricultural settings [26-28], including a fullscale, integrated bioenergy system through the University of Tennessee [29]. Pine intercropping is also not new; the literature includes examples of plot trials, for example intercropping with low-value trees [30] and switchgrass [31, 32].

The Catchlight joint venture brought together expertise in natural resources from Weyerhaeuser and energy from Chevron and worked to fill technology gaps. We, the authors, were primarily involved in feedstock supply and sustainability research. While our sustainability research is being published, many of the planning decisions and operational trial results were not public. To capture the important lessons from these and gain additional insight into project history, we interviewed others in management, planning, operations, and logistics, and the following reflects our experience and that of those we interviewed. As part of the bioenergy project scoping, planners from Weyerhaeuser, Chevron, and the joint venture 


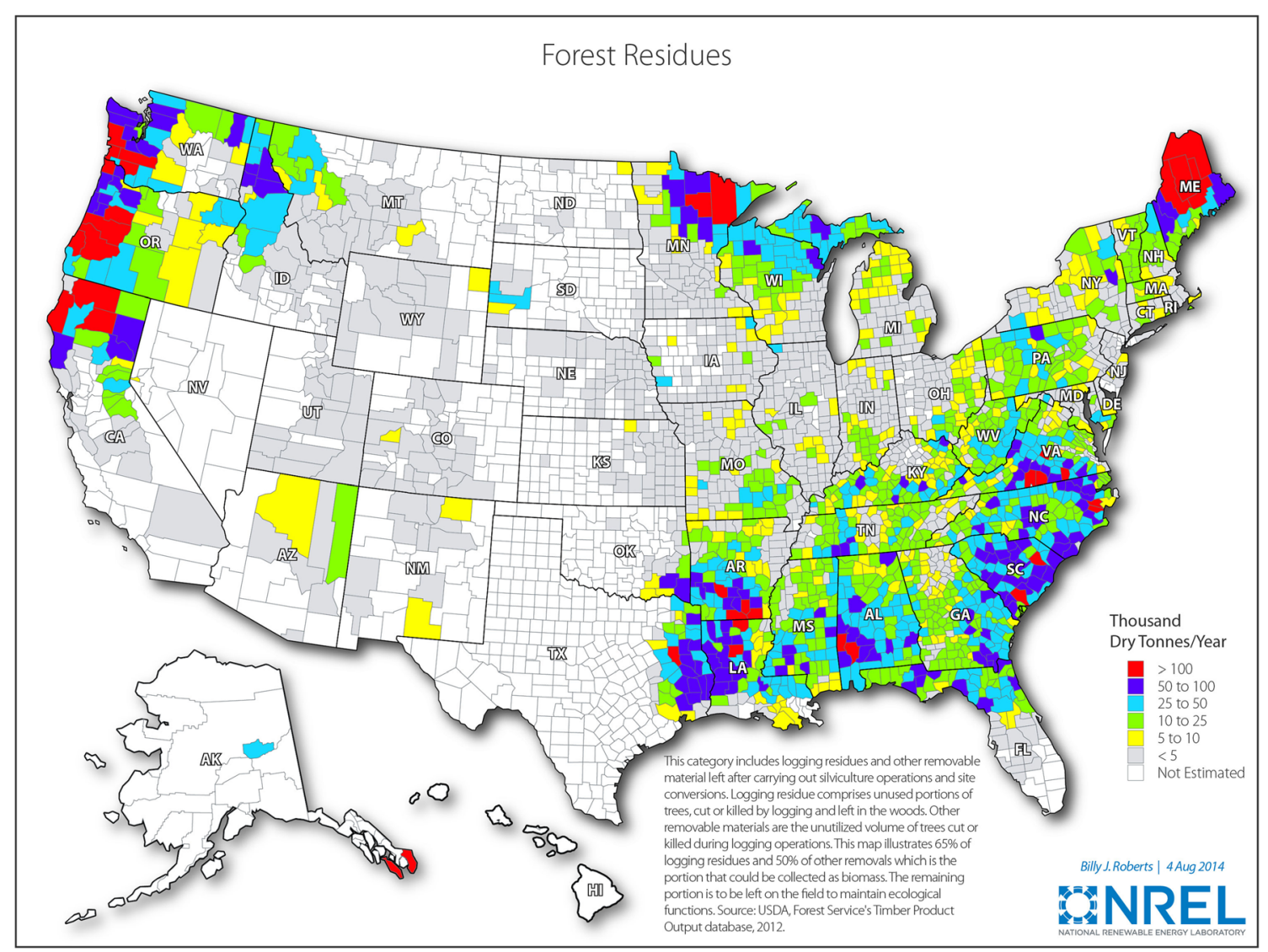

Fig. 1 Forest residues beyond that needed for ecological function [72]

evaluated barriers to bioenergy supply. Major barriers were overall demand including energy and feedstock markets; government policy, mandates, and incentives; environmental effects on biodiversity, water, and soil; carbon fate and accounting methodology; seed source and availability; planting methods and establishment success; switchgrass productivity; competition between pine and switchgrass; equipment and contractor availability; harvesting logistics and efficiency; and transportation costs. Plans were put in place to simultaneously address the major research gaps and scale up sustainable feedstock production. Seventeen bioenergy plants were planned by 2029 , with the first commercial plant on line in 2014.

Operational tracts and studies were installed in 2008 and continued until 2012 when it became clear that with dropping energy prices, reduced policy imperatives, and no breakthroughs in scaled conversion technology efficiency, pine/switchgrass intercropping was economically infeasible except under the most productive conditions. As Alan Shaw, former CEO of Codexis advanced biofuel company, said about cellulosic conversion, it is "not a promising place to start producing commodity chemicals and fuels where 80 percent of the cost is feedstock."[33]. Where research into engineered system components can occur rapidly, research and development of feedstock cannot move faster than crop establishment and growth, and perennial, forest-based systems face additional challenges. Competition between pine and switchgrass is a major component of the economic [34] and sustainability equation, yet switchgrass does not reach maturity for 3 years. Site preparation and sowing of switchgrass were expected to cause high erosion initially [35], yet once established, switchgrass is a very effective sediment control [36] and has even been shown to be effective in mitigated gully erosion [37]. Biodiversity and water quality components of sustainability research required a pre-and post-treatment period, further increasing length of time needed for results. However, results can be extrapolated to many intensive forest-based biofuel practices, and although the operational studies concluded, sustainability work has continued and is yielding useful insights.

Operational studies included in-field operations, logistics, plant and system productivity, and effects on soil quality and carbon stocks. Trials examined switchgrass species optimization, provenance, spacing and configuration, fertilization rates and timing, herbicide prescriptions, shading effects, planting equipment and methods, harvest timing and frequency, site preparation, pine/switchgrass competition, and ash content. The intercropping system was patented [38], and while some studies were proprietary, others overlapped sustainability work and were published (e.g., [39-44]). Many trials were 
conducted in Lenoir County, NC, an experimental site established in 2008 for soil and carbon sustainability work [45]. Other field trials, environmental research sites, and approximately 30 full-scale operational tracts were installed across Weyerhaeuser's ownership in Mississippi, Alabama, and North Carolina. These to-scale trials revealed several barriers to economically viable and environmentally sustainable feedstock production.

\section{Site Planning}

Although multiple row spacings were studied, switchgrass was operationally planted between pine spaced in rows $6 \mathrm{~m}$ apart (Fig. 2). Plot studies demonstrate lower switchgrass height and productivity on edges nearest to pine, due to competition and shading [39, 40]. Effect magnitude increases with pine age and competition for resources, including light. Although a shading effect is not apparent early in the intercropping cycle [40] and has been hypothesized to help young switchgrass outcompete other grass [46], it greatly limits productivity as switchgrass matures [39].

Correlated with row spacing, age of pine at switchgrass planting has implications for switchgrass productivity and site erosion. Delaying switchgrass site preparation and planting until 2 years after plantation establishment leaves residuals time to decay, providing more uniform ground conditions, improving establishment efficiency and success. Preliminary results also found desynchronized planting reduced water quality response to switchgrass site preparation $[47,48]$ comparison to simultaneous planting. However, switchgrass loses significant productivity under a shading equivalent of $6-8$ - year-old pine [39], moving switchgrass production to a 4-6year window in a 25 -year pine rotation.

These sites, like all Weyerhaeuser US plantations, were managed under SFI requirements, and state Best Management Practices (BMPs) for forestry were followed. Forested riparian buffers and non-riparian buffers, common in steeper slopes and wet areas, reduced operable area. Steeper sites and sites with broken microtopography were also excluded. Trees were planted on contour, and in sites with steep and dissected relief, planting rows became broken and also intersected, making operations less efficient. While these practices provided soil and water quality protection, areas left in trees shaded switchgrass and reduced and fragmented planting area. Other best practices, such as sinuous contour planting, limited equipment type and maneuverability and required more fuel.

\section{Operations}

Establishing an agricultural crop on forest land proved to be challenging, requiring equipment and experience not typical of forest operators. Although intercropped sites were limited to lower slopes, operators used their judgment and experience to further restrict operations within a tract to limit erosion, reducing the area site prepared for switchgrass by approximately $25 \%$ in upland areas [49].

After plantation harvest, but before planting pine or switchgrass, sites were cleaned with a brush rake, an expensive and slow process. The ground had to be dry enough to support a large bulldozer, but still have enough moisture for optimal sowing. Intercropped areas had to be further cleared so that
Fig. 2 An intercropped site in Greene County, Alabama, with bales from previous year harvest

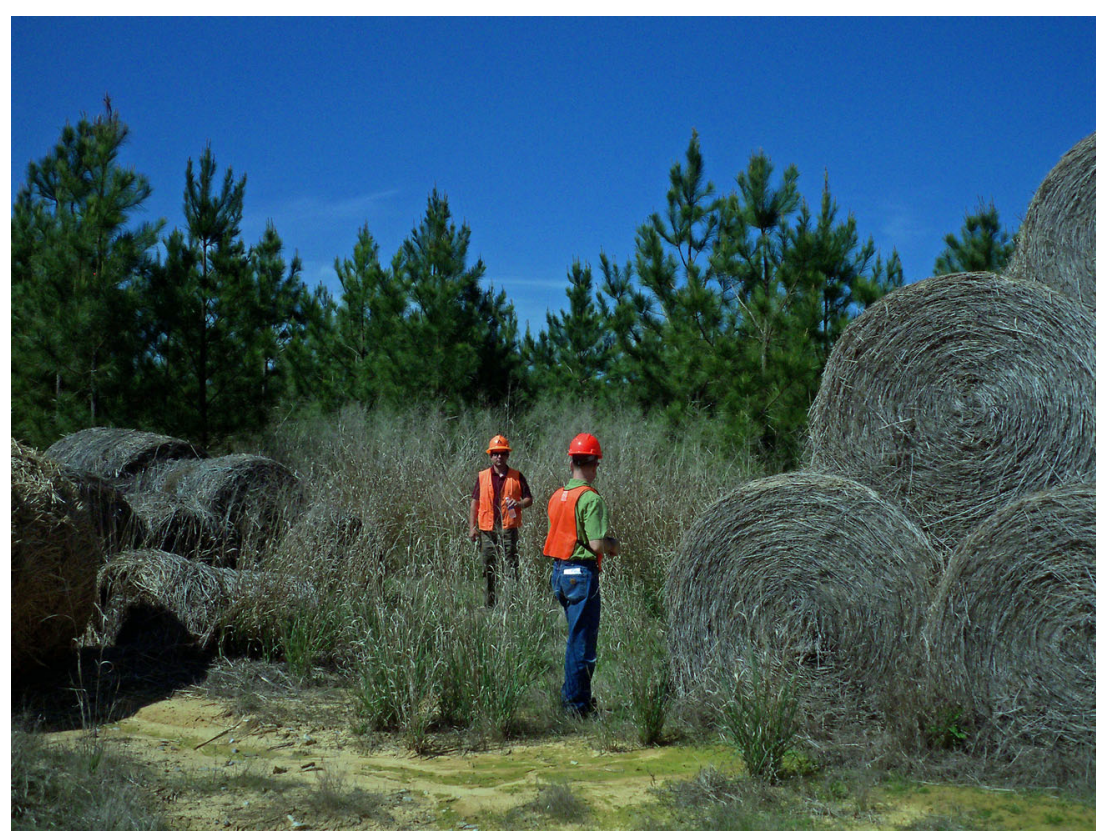


the seeds were sown in mineral soil, while avoiding erosion. Even with additional clearing, considerable forest residue remained, slowing site preparation considerably. Planting areas, while very smooth by forestry standards, were much rougher than agricultural sites.

The first attempts at sowing used a seed drill designed for row crops. However, in many sites, slope, ground undulations, and rills led to large variations in seed placement, with some sown too deeply and other dropped on the soil surface. Experiments led to improved techniques, and in subsequent attempts, soil was disked three times with a tractor and seed was broadcast followed by a light harrowing using an allterrain vehicle with a chain bar. This produced more optimal soil moisture conditions and seed depth leading to much more successful germination.

Loblolly pine prefers soil $\mathrm{pH}$ from 4.5-7.0 [50] but switchgrass prefers a $\mathrm{pH}$ of 5.5-6.5 [28], and productivity is reduced in lower $\mathrm{pH}$ soils. Pine plantations are fertilized at low average annual rates, and additional fertilization was needed for switchgrass. Pine, planted as seedlings, are not affected by localized standing water, but this reduced productivity of or killed switchgrass. Competition from diverse seed reservoirs, not present in highly cultivated agricultural land, required sitespecific herbicide prescriptions.

Agricultural equipment and techniques had to be modified for mowing and baling. Pine rows closed over time, and switchgrass growth hid obstacles. Contour plantings, efficient in preventing erosion, require much more equipment maneuverability and slowed each equipment pass. Costs per bale were approximately double those from an agricultural field.

\section{Sustainability}

To understand sustainability of intercropping, research was conducted for carbon balance and environmental effects; environmental research included biodiversity, soil quality, and water resources. Biodiversity studies covered plants, herpetofauna, and large and small mammals [51-59]. Soil quality, GHG, and carbon life cycle analyses were conducted. [31, 40-42, 44].

In research watersheds, switchgrass was planted into a young pine stand or co-planted during with pine along with stands of mid-rotation pine, young pine, and switchgrass only. Early switchgrass success was low, and the sites were replanted and overseeded, delaying the project by a year and extending the final growing season to 2015. Publications to date evaluate methods and models, reference site dynamics, plot trials, pre-treatment or site preparation periods, and early data $[47,60-66]$; however, general observations can be made. A visual survey confirmed water quality analysis [47] that erosion associated with site prep and sowing was minimized by existing pine rows, which stopped almost all sediments. Coplanted stands were clear of vegetation for a longer time and had none of the litter accumulation associated with even young pine. Water use has been a major concern in biofuel feedstock $[67,68]$, but early estimates show intercropping would use slightly less water than pine plantations they replace [50, 69]. The final analyses are not complete, but properly implemented pine/switchgrass intercropping appears to maintain ecological functions of the forest.

\section{Conclusions}

To make a significant contribution to renewable fuel supply, forest-based biomass must be grown and harvested sustainably and efficiently. Intense management of a highproductivity crop must be done in a way that maintains ecosystem services of managed forests. Operational plantings across feedstocks show much less yield than plot trials predict [70]; this discrepancy between modeled and actual supply could harm food and bioenergy markets and threaten plans for renewable fuel [71]. Identifying and addressing the benefits and challenges of forest-based biomass feedstock systems will help ensure renewable fuel supply for our future.

\section{Compliance with Ethical Standards}

Conflict of Interest Jami Nettles, Peter Birks, Eric Sucre, and Robert Bilby declare that they have no conflict of interest.

Human and Animal Rights and Informed Consent This article does not contain any studies with human or animal subjects performed by any of the authors.

\section{References}

1. Lauri P, Havlík P, Kindermann G, Forsell N, Böttcher H, Obersteiner M. Woody biomass energy potential in 2050. Energy Policy. 2014;66:19-31.

2. Skog K, Stanturf J, Forest biomass sustainability and availability, presented at the Sustainable Production of Fuels, Chemicals, and Fibers from Forest Biomass. Zhu, J., X. Zhang, and X. Pan (eds.). American Chemical Society Symposium Series, 2011, vol. 1067, pp. 3-25.

3. Perlack RD, Wright LL, Turhollow AF, Graham RL, Stokes BJ, Erbach DC. Biomass as feedstock for a bioenergy and bioproducts industry: the technical feasibility of a billion-ton annual supply. DTIC Document. 2005.

4. Sample VA. What role will forests play in America's long-term energy future? J Sustain For. 2013;32(1-2):1-13.

5. National Research Council (US). Committee on Economic and Environmental Impacts of Increasing Biofuels Production, Renewable fuel standard: potential economic and environmental effects of US biofuel policy. National Academies Press, 2011.

6. Sedjo RA, Sohngen B. Wood as a major feedstock for biofuel production in the United States: impacts on forests and international trade. J Sustain For. 2013;32(1-2):195-211. 
7. Shell D. Wood-based biofuel development needs positive policy. Wood Bioenergy. 2015;7(4):18-21.

8. Galik CS, Abt R, Wu Y. Forest biomass supply in the southeastern United States-implications for industrial roundwood and bioenergy production. J For. 2009;107(2):69-77.

9. Kraxner F, Nordström E-M, Havlík P, Gusti M, Mosnier A, Frank $\mathrm{S}$, et al. Global bioenergy scenarios-future forest development, land-use implications, and trade-offs. Biomass Bioenergy. 2013;57:86-96.

10. Abt RC, Abt KL. Potential impact of bioenergy demand on the sustainability of the southern forest resource. J Sustain For. 2013;32(1-2):175-94.

11. Abbas D, Arnosti D. Economics and logistics of biomass utilization in the superior national forest. J Sustain For. 2013;32(1-2):41-57.

12. Eisenbies MH, Vance ED, Aust WM, Seiler JR. Intensive utilization of harvest residues in southern pine plantations: quantities available and implications for nutrient budgets and sustainable site productivity. BioEnergy Res. 2009;2(3):90-8.

13. Gan J, Smith C. Availability of logging residues and potential for electricity production and carbon displacement in the USA. Biomass Bioenergy. 2006;30(12):1011-20.

14. Langholtz MH, Caffrey KR, Barnett EJ, Webb E, Brummette MW, Downing M. Demonstration of the BioBaler harvesting system for collection of small-diameter woody biomass. Oak Ridge National Laboratory Report. 2011.

15. do Canto JL, Klepac J, Rummer B, Savoie P, Seixas F. Evaluation of two round baling systems for harvesting understory biomass. Biomass Bioenergy. 2011;35(5):2163-70.

16. Rummer B, Klepac J, Thompson J. Technology for biomass feedstock production in southern forests and GHG implications, Gen. Tech. Rep.-South. Res. Stn. USDA For. Serv., no. SRS-156, pp. 278-282, 2012.

17. AF\&PA, AF\&PA White Paper: Sustainable Forestry and Certification Programs in the United States, American Forest \& Paper Association. <http://www.afandpa.org/docs/default-source/ one-pagers/sustainable-forestry-and-certification-programs-in-theunited-states.pdf $>$

18. Johnson DW, Curtis PS. Effects of forest management on soil C and N storage: meta analysis. For Ecol Manag. 2001;140(2):227-38.

19. Sanchez FG, Scott DA, Ludovici KH. Negligible effects of severe organic matter removal and soil compaction on loblolly pine growth over 10 years. For Ecol Manag. 2006;227(1):145-54.

20. Fox TR. Sustained productivity in intensively managed forest plantations. For Ecol Manag. 2000;138(1):187-202.

21. Compton J, Cole D. Impact of harvest intensity on growth and nutrition of successive rotations of Douglas-fir, FRI Bull-For Res Inst N Z For Serv, 1991.

22. Eisenbies MH, Burger JA, Aust WM, Patterson SC. Soil physical disturbance and logging residue effects on changes in soil productivity in five-year-old pine plantations. Soil Sci Soc Am J. 2005;69(6):1833-43.

23. Laiho R, Sanchez F, Tiarks A, Dougherty PM, Trettin CC. Impacts of intensive forestry on early rotation trends in site carbon pools in the southeastern US. For Ecol Manag. 2003;174(1):177-89.

24. Mälkönen E. Effect of whole-tree harvesting on soil fertility., 1976.

25. Cantor R, Rizy C. Biomass energy: exploring the risks of commercialization in the United States of America. Bioresour Technol. 1991;35(1):1-13.

26. McLaughlin S, Bouton J, Bransby D, Conger B, Ocumpaugh W, Parrish D, et al. Developing switchgrass as a bioenergy crop. Perspect New Crops New Uses. 1999;282.

27. Sokhansanj S, Mani S, Turhollow A, Kumar A, Bransby D, Lynd L, et al. Large-scale production, harvest and logistics of switchgrass (Panicum virgatum L.)-current technology and envisioning a mature technology. Biofuels Bioprod Biorefin. 2009;3(2):124.
28. Douglas J, Lemunyon J, Wynia R, Salon P. Planting and managing switchgrass as a biomass energy crop. USDA-NRCS, Technical Note No. 3, 2009.

29. Tiller K. Tennessee case study in full-scale development and integration of switchgrass feedstocks with biorefinery operations: genera energy and UT biofuels initiative. Ind Biotechnol. 2011;7(5): 357-64.

30. Scott DA, Tiarks A. Dual-cropping loblolly pine for biomass energy and conventional wood products. South J Appl For. 2008;32(1): 33-7.

31. Blazier MA, Clason TR, Liechty HO, Leggett ZH, Sucre EB, Roberts SD, et al. Nitrogen and carbon of switchgrass, loblolly pine, and cottonwood biofuel production systems in the Southeast United States. For Sci. 2015;61(3):522-34.

32. Liechty HO, Blazier M, Pelkki M, White D Jr, Robinson Z. The potential for using agroforests for bioenergy production in the Lower Mississippi Alluvial Valley, 2012

33. Bullis K. Biofuels companies drop biomass and turn to natural gas. MIT Technology Review. 2012.

34. Susaeta A, Lal P, Alavalapati J, Mercer E, Carter D. Economics of intercropping loblolly pine and switchgrass for bioenergy markets in the southeastern United States. Agrofor Syst. 2012;86(2):28798.

35. Nyakatawa E, Mays D, Tolbert V, Green T, Bingham L. Runoff, sediment, nitrogen, and phosphorus losses from agricultural land converted to sweetgum and switchgrass bioenergy feedstock production in north Alabama. Biomass Bioenergy. 2006;30(7):655-64.

36. Dabney S, Meyer L, Dunn G, Foster G, Alonso C. Stiff-grass hedges, a vegetative alternative for sediment control. Proceedings of the Sixth Federal Interagency Sedimentation Conference. 1996;2:62-9.

37. Shields F, Dabney S, Langendoen E, Temple D. Control of gully erosion using stiff grasses. Int J Sediment Res. 2005;20(4):319.

38. Bigelow FH, Duzan H, Kumar VH, Lowery RH. Methods of managing timberland. U.S. Patent 8,042,300, issued October 25, 2011.

39. Albaugh JM, Albaugh TJ, Heiderman RR, Leggett Z, Stape JL, King K, et al. Evaluating changes in switchgrass physiology, biomass, and light-use efficiency under artificial shade to estimate yields if intercropped with Pinus taeda L. Agrofor Syst. 2014;88(3):489-503.

40. Albaugh JM, Sucre EB, Leggett ZH, Domec J-C, King JS. Evaluation of intercropped switchgrass establishment under a range of experimental site preparation treatments in a forested setting on the Lower Coastal Plain of North Carolina, USA. Biomass Bioenergy. 2012;46:673-82.

41. Albaugh JM, Domec J-C, Maier CA, Sucre EB, Leggett ZH, King JS. Gas exchange and stand-level estimates of water use and gross primary productivity in an experimental pine and switchgrass intercrop forestry system on the Lower Coastal Plain of North Carolina, USA. Agric For Meteorol. 2014;192:27-40.

42. Minick KJ, Strahm BD, Fox TR, Sucre EB, Leggett ZH, Zerpa JL. Temporal patterns of soil nutrient availability in: Southern loblolly pine forests intercropped with switchgrass. San Antonio, TX: Proceedings of the soil Science Society of America International meetings; 2011.

43. Shrestha A. Greenhouse Gas fluxes and root productivity in a switchgrass (Panicum Virgatum L.) and loblolly pine (Pinus Taeda L.) intercropping system, Master's thesis. Blacksburg: Virginia Polytechnic Institute and State University; 2013.

44. Strickland MS, Leggett ZH, Sucre EB, Bradford MA. Biofuel intercropping effects on soil carbon and microbial activity. Ecol Appl. 2015;25(1):140-50.

45. Leggett Z, Sucre E. Lenoir 1 intercropping sustainability study site description. Federal Way, Washington: Weyerhaeuser Company; 2012. Technical Note.

46. Blazier M. Switchgrass and trees. La Agric. 2009. 
47. Bennett EM. Hydrology and water quality impacts of loblolly pine (Pinus taeda) and switchgrass (Panicum virgatum) intercropped systems in upland southeastern forested watersheds: results after three years in Alabama, North Carolina State University, 2013.

48. Bennett EM, Birgand F, Chescheir G, Allen E, Appelboom T, Lagace R, Nettles J. hydrology and water quality impacts of site preparation for loblolly pine (Pinus taeda) and switchgrass (Panicum virgatum) intercropping in upland forested watersheds in Alabama, Revis. Biomass Bioenergy.

49. Nettles J, Youssef M, Cacho J, Grace J, Leggett Z, Sucre E. The water quality and quantity effects of biofuel operations in pine plantations of the southeastern USA, IAHS-AISH Publ, 2011; 115-120.

50. Londo AJ, Carter RC, Kushla JD. Soil pH and tree species suitability in Mississippi. Southern Regional Extension Forestry: Mississippi State University; 2006.

51. Briones KM, Homyack JA, Miller DA, Kalcounis-Rueppell MC. Intercropping switchgrass with loblolly pine does not influence the functional role of the white-footed mouse (Peromyscus leucopus). Biomass Bioenergy. 2013;54:191-200.

52. Fritts S, Moorman C, Grodsky S, Hazel D, Homyack J, Farrell C, et al. Shrew response to variable woody debris retention: implications for sustainable forest bioenergy. For Ecol Manag. 2015;336: $35-43$.

53. Homyack JA, Aardweg Z, Gorman TA, Chalcraft DR. Initial effects of woody biomass removal and intercropping of switchgrass (Panicum virgatum) on herpetofauna in eastern North Carolina. Wildl Soc Bull. 2013;37(2):327-35.

54. Homyack JA, Lucia-Simmons KE, Miller DA, Kalcounis-Rueppell M. Rodent population and community responses to forest-based biofuel production. J Wildl Manag. 2014;78(8):1425-35.

55. Iglay RB, Riffell SK, Miller DA, Leopold BD. Effects of switchgrass intercropping and biomass harvesting on plant communities in intensively managed pine stands. Proceedings from sun grant national conference: science for biomass feedstock production and utilization. 2012;1.

56. King KL, Homyack JA, Wigley TB, Miller DA, KalcounisRueppell MC. Response of rodent community structure and population demographics to intercropping switchgrass within loblolly pine plantations in a forest-dominated landscape. Biomass Bioenergy. 2014;69:255-64.

57. Loman ZG, Riffell SK, Miller DA, Martin JA, Vilella FJ. Site preparation for switchgrass intercropping in loblolly pine plantations reduces retained trees and snags, but maintains downed woody debris. Forestry. 2013;86(3):353-60.

58. Loman ZG, Riffell SK, Wheat BR, Miller DA, Martin JA, Vilella FJ. Breeding bird community response to establishing intercropped switchgrass in intensively-managed pine stands. Biomass Bioenergy. 2014;67:201-11.

59. Riffell S, Verschuyl J, Miller D, Wigley TB. Potential biodiversity response to intercropping herbaceous biomass crops on forest lands. J For. 2012;110(1):42-7.

60. Cacho JF. Impacts of bioenergy feedstock production on soil physical properties, soil water and nitrogen dynamics, and shallow groundwater quality of a drained forest. North Carolina State University, 2013.

61. Muwamba A, Amatya D, Ssegane H, Chescheir G, Appelboom T, Tollner E, et al. Effects of site preparation for pine forest/ switchgrass intercropping on water quality. J Environ Qual. 2015;44(4):1263-72.

62. Neal AW. Soil carbon and nitrogen dynamics across the hillsloperiparian interface in adjacent watersheds with contrasting cellulosic biofuel systems, 2014.

63. Ssegane H, Amatya DM, Chescheir GM, Skaggs WR, Tollner EW, Nettles JE. Consistency of hydrologic relationships of a paired watershed approach, 2013.

64. Ssegane H, Amatya D, Muwamba A, Chescheir G, Appelboom T, Tollner E, et al. Hydrologic calibration of paired watersheds using a MOSUM approach. Hydrol Earth Syst Sci Discuss. 2015;12(1): 245-79.

65. Tian S, Youssef MA, Skaggs RW, Amatya DM, Chescheir G. DRAINMOD-FOREST: integrated modeling of hydrology, soil carbon and nitrogen dynamics, and plant growth for drained forests. J Environ Qual. 2012;41(3):764-82.

66. Tian S, Youssef MA, Skaggs RW, Amatya DM, Chescheir GM. Modeling water, carbon, and nitrogen dynamics for two drained pine plantations under intensive management practices. For Ecol Manag. 2012;264:20-36.

67. Berndes G. Bioenergy and water - the implications of large-scale bioenergy production for water use and supply. Glob Environ Chang. 2002;12(4):253-71.

68. Dominguez-Faus R, Powers SE, Burken JG, Alvarez PJ. The water footprint of biofuels: a drink or drive issue? Environ Sci Technol. 2009;43(9):3005-10.

69. Nettles JE, Leggett ZH. Extent and distribution of sustainable intensive forest biofuel practices, vol. 1. New Orleans: Proceedings of the 2012 Sun Grant National Conference; 2012. p. 279-83.

70. Searle SY, Malins CJ. Will energy crop yields meet expectations? Biomass Bioenergy. 2014;65:3-12.

71. Searle $S$, Malins C. A reassessment of global bioenergy potential in 2050. GCB Bioenergy. 2015;7(2):328-36.

72. Roberts BJ. Forest residues, National Renewable Energy Laboratories. 2014. <http://www.nrel.gov/gis/images/biomass 2014/National-Biomass-Forest-2014-01.jpg> 